\title{
Participation of Rural Women in Agriculture in Selected States in Niger Delta, Nigeria
}

\author{
ODUBO Tonye Vivien", OBAFEMI Andrew A., EMENIKE Gladys C \\ Department of Geography and Environmental Management, Faculty of Social Sciences, University of Port \\ Harcourt, Choba, Rivers State, Nigeria. \\ *Corresponding Author: ODUBO Tonye Vivien, Department of Geography and Environmental \\ Management, Faculty of Social Sciences, University of Port Harcourt, Choba, Rivers State. Nigeria.
}

\begin{abstract}
Studies have shown that women in Nigeria play a crucial role in food security due to their active involvement in agriculture. However, they are viewed as insignificant partners and not accorded due attention. As a result of this, women suffer numerous limitations. Generalizing female roles in agriculture as well as their contributions could be misleading because it varies according to geographical and cultural context. Thus, this research looked at rural women's participation in agriculture within the Ijaw ethnic context. 400 households were selected through a double stage random sampling technique from 44 rural communities in 22 Local government areas, across 5 States in the Niger Delta. Relevant data were gathered with the help of a semi-structured interview schedule and analysed using the descriptive method. The analysis revealed that women who engaged in agriculture were more than men across states and ecological zones of the study area. Women constitute $78.6 \%$ of labour in agriculture amongst households in the mangrove forest and coastal zone and $71.1 \%$ in freshwater swamp zone. Women constitute $51.4 \%$ of labour in agriculture in Akwa Ibom State, $78.9 \%$ in Rivers State, $73.1 \%$ in Bayelsa State, $74 \%$ in Delta State and $77.8 \%$ in Ondo State. Overall, women constitute above $74.9 \%$ of labour in agriculture amongst households in the study area. The study recommended that women and men engaged in agriculture should be proportionally represented in the planning and implementation process of agricultural policies, either by the male-female ratio of agricultural labour in the regions or by the male-female ratio of the population of the area involved.
\end{abstract}

Keywords: Women, Rural, Engaged in agriculture, Agricultural labour, Niger Delta

\section{INTRODUCTION}

Women are thus vital to the growth of agriculture as well as related fields. They are active in producing, processing, cooking and serving of food amongst other households' chores (Abdullahi, Abdullahi, \& Mohammed, 2012). By Conservative estimate, female farmers cultivate over 50\% of every food grown in several regions of the earth most especially in underdeveloped countries (UNHRC), 2010, cited in Institute of Development Studies (IDS), 2012). They make up 43\% of the world's agricultural workforce, which extends to $70 \%$ in certain countries (FAO, 2011). Small scale farmers in African countries provide $80 \%$ of agricultural production and these are mainly rural women (Saquina, 2013).

More womenfolk are active in agriculture than their male counterparts in Sub-Saharan African (SSA) countries (Ogunlela \& Mukhtar 2009). Despite this, men are known to take farm management decisions. Unfortunately, female farmers are neglected, particularly concerning deciding and influencing agricultural policies. Such policies, which are geared towards improving food security as well as production, neglect females' role in both production and decision-making within the home (Ogunlela \& Mukhtar, 2009). Rahman (2008) and Damisa and Yohanna (2007) are of opinion that, although it is of common knowledge that womenfolk are key elements in the development of agriculture in Nigeria, their contribution to agricultural policy-making process is not significant.

Furthermore are not helpful when data that conceal the women share in agricultural labour is put out. This undermines the efforts of women and aids their neglect in development processes. In Nigeria, women constitute $60-80 \%$ of the agricultural labour; they produce two-thirds of the total food crops (Action aid, 2015). In Ondo State, almost $80 \%$ of the food being consumed is cultivated and processed by rural women (Afolabi, 2008). 76\% of women from Bauchi and Oyo States are involved 
in farming activities or working in farms that belong to their husbands (Yahaya, 2002, cited in Fabiyi, Danladi, Akande \& Mahmood, 2007). Women's involvement in food production varies from $80 \%$ in Congo to $30 \%$ in Sudan. They do their part in ensuring growth in general agricultural production in addition to food security, while being primarily the source for the food crops (FAO, 1995).

World Bank (2015) opines that women make up far less than $60-80 \%$ of agricultural labour in developing countries. Women constitute an average of $40 \%$ of agricultural labour across Ethiopia, Malawi, Niger, Uganda and Nigeria. Separately, women constitute a little over $50 \%$ in Tanzania, Uganda and Malawi; $24 \%$ in Niger; $37 \%$ in Nigeria and 29\% in Ethiopia. The paper reported that in Nigeria, women's contribution ranges from $32 \%$ in the north to $51 \%$ in the south. It indicated confidence in the results due to the fact that it was consistent with expectation. The method of measurement used in the analysis, was the estimation of each household member's labour input per plot for each agricultural activity. It is unclear if the estimate is based on hours spent in each activity per plot or the proportion of work done in each activity per plot.

SOFA team and Doss (2011) also disagree that women in developing countries constitute up to 60$80 \%$ of agricultural labour. They believe this statistic emanated from the United Nations Economic Commission for Africa years back and although similar remarks as it concerns developing countries still persist, available data portray the fact that women contribute to agricultural labour, the estimates are not representative of the developing world. They opined that in most sub-Saharan Africa women contribute less to agriculture except in parts of Cameroun. Two types of data for estimating women share in agricultural labour were reported in their work. The data include: statistics of the share of women in the economically active population in agriculture, that is records of individuals who report that agriculture is their main economic activity and the time-use surveys, which records the time spent by men and women in different activities. They indicated that the economically active data is the most thorough means of measuring women participation in agriculture but can underestimate female labour share if proper caution is not taken while the time-use survey is not nationally representative and not effective for generalizing results. However, they believe that the results of women labour share in agriculture can vary with time, the methods used in ascertaining women share in agriculture labour as well as the region in question. Therefore gender roles in agriculture should be considered within their specific geographic and cultural context and not generalized (SOFA team \& Doss, 2011). In this paper, the proportion of agricultural labour force provided by women in households across the state and the ecological regions in the study area was ascertained.

\section{MATERIALS AND MeTHODS}

The study covered Local Government Areas (LGAs) and States in the Niger Delta, Nigeria where the people of Ijaw extraction are predominant. Thus, 22 LGAs across 5 States met this condition and were selected as the study area. Then, 2 communities from every LGA were randomly selected. Thereafter, 400 households were randomly chosen from the 44 communities. The number of households chosen from each community was done proportionately according to the number of households in each community.

Figure 1 shows the study area. The study area is located within the Niger Delta region of Nigeria. The area lies within latitudes $4^{\circ} 0^{\prime} 0^{\prime \prime} \mathrm{N}$ and $7^{\circ} 0^{\prime} 0^{\prime \prime} \mathrm{N}$ of the equator and longitudes $4^{0} 0^{\prime} 0^{\prime \prime} \mathrm{E}$ and $8^{0} 30^{\prime} 0^{\prime \prime} \mathrm{E}$ of the Greenwich meridian. The study area has two main ecological regions. The mangrove forest and coastal zone and the fresh water swamp forest zone. The main occupations of the people are: fishing in the mangrove zone and subsistence farming and fishing in the freshwater forest. They are also engaged in palm oil milling, lumbering, palm wine tapping and local gin making, trading, carving and weaving among others.

A cross-sectional research survey was carried out through the help of semi-structured interview schedules. The study applied descriptive tools to analyze and deduce results in accordance with the set objective of the study. Data on the major source of livelihood of employed household members in various states of ecological zones were collected. This data was gender-segregated at the point of collection and analyzed with simple percentages, tables and charts. Data on the employed population provide an efficient measure for the participation of women in agriculture. An individual is regarded as being part of the agricultural labour force if they indicate that agriculture is their major source of livelihood (SOFA team \& Doss, 2011) 


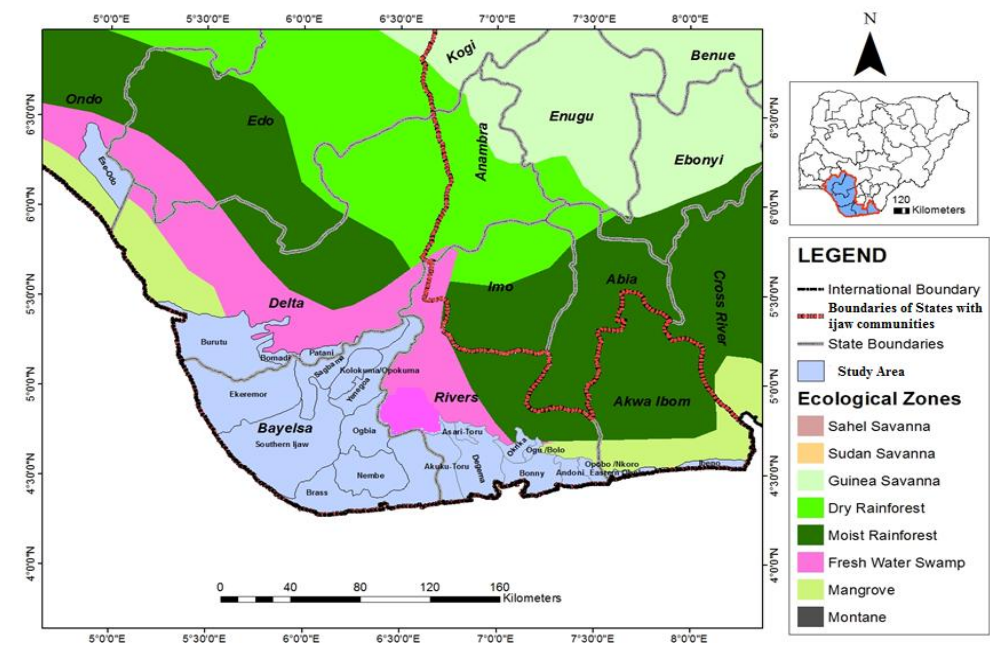

Figure1. The study area showing 22 Local Government Areas (LGAs) in the Niger Delta region.

\section{RESUltS AND DISCUSSION}

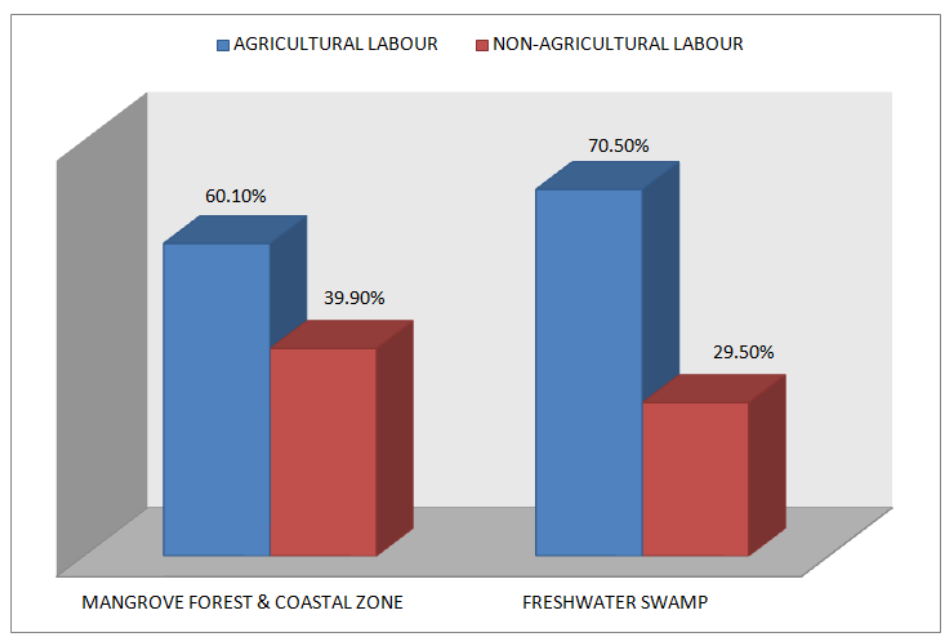

Figure2. Distribution of labour amongst households across ecological zones in the study area

The distribution of labour amongst households across ecological zones in the study area is presented in figure 2. Amongst household members, there are more people engaged in agricultural jobs than non-agricultural jobs in the study area. In the mangrove forest and coastal zone, $60.1 \%$ of the household members are largely engaged in agriculture while $38.9 \%$ are mainly engaged in nonagricultural jobs. In the freshwater swamp, $70.5 \%$ of the household members are largely engaged in agriculture while $29.5 \%$ are mainly engaged in non-agricultural jobs.

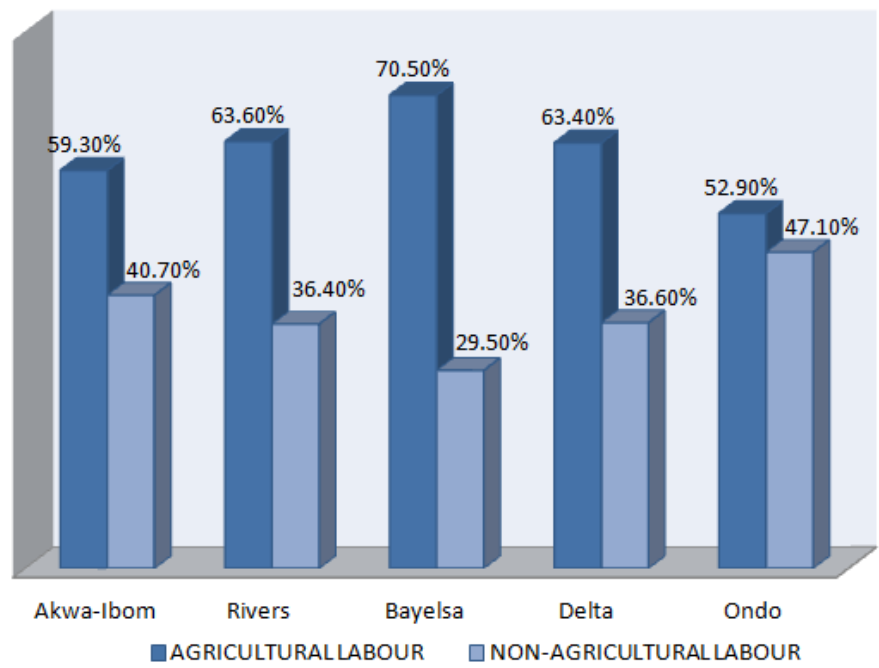

Figure3. Distribution of labour amongst households across States in the study area 
The distribution of labour amongst households across States in the study area is presented in figure 3. Across State, it is still evident that more household members earn most of their income from agriculture. In Akwa Ibom State, 59.3\% of household member are engaged in agriculture and 40.4\% are engaged in non-agricultural jobs. In Rivers State, $63.6 \%$ of the household members are engaged in agriculture and $36.4 \%$ are engaged in non-agricultural jobs.

Table1. Gender distribution of agricultural and non-agricultural labour in households across ecological zones in the study area

\begin{tabular}{|l|l|l|l|}
\hline $\begin{array}{l}\text { Distribution of } \\
\text { occupation by gender }\end{array}$ & $\begin{array}{l}\text { Mangrove forest/coastal } \\
\text { zone }\end{array}$ & Freshwater swamp & Total \\
\hline Agricultural labour & & & \\
\hline Female & $243(78.6)$ & $219(71.1)$ & $462(74.9)$ \\
\hline Male & $66(21.4)$ & $89(28.9)$ & $155(25.1)$ \\
\hline Non-agricultural labour & & & \\
\hline Female & $77(37.6)$ & $53(41.1)$ & $130(38.9)$ \\
\hline Male & $128(62.4)$ & $76(58.9)$ & $204(61.1)$ \\
\hline
\end{tabular}

Table 1 shows the gender distribution of labour; agricultural or non-agricultural labour force amongst household members within the ecological zones in the study area. Most household members engaged in agriculture are female but males are more engaged in non-agricultural jobs than females. In the mangrove forest and coastal zone, among household members, females consist of $78.6 \%$ of the agricultural labour and males, $21.4 \%$. Females consist of $37.6 \%$ of non-agricultural labour and males, $62.4 \%$. In the freshwater swamp, females consist of $71.1 \%$ of the agricultural labour and males, $28.1 \%$. In contrast, females consist of $37.6 \%$ of non-agricultural labour and males, $62.4 \%$.

Table2. Distribution of agricultural and non-agricultural labour in households across State in the study area

\begin{tabular}{|l|l|l|l|l|l|l|}
\hline $\begin{array}{l}\text { Distribution of } \\
\text { occupation by gender }\end{array}$ & Akwa Ibom & Rivers & Bayelsa & Delta & Ondo & Total \\
\hline Agricultural labour & & & & & & \\
\hline Female & $18(51.4)$ & $157(78.9)$ & $182(73.1)$ & $77(74.0)$ & $28(77.8)$ & $462(74.9)$ \\
\hline Male & $17(48.6)$ & $42(21.1)$ & $67(26.9)$ & $27(26.0)$ & $8(22.2)$ & $155(25.1)$ \\
\hline Non-agricultural labour & & & & & & \\
\hline Female & $9(37.5)$ & $47(41.2)$ & $43(41.3)$ & $18(30.0)$ & $13(40.6)$ & $130(38.9)$ \\
\hline Male & $15(62.5)$ & $67(58.8)$ & $61(58.7)$ & $42(70.0)$ & $19(59.4)$ & $204(61.1)$ \\
\hline
\end{tabular}

Table 2 shows the gender distribution of employed households' members that are engaged in agricultural or non-agricultural jobs as their major source of livelihood in households across States in the study area. Most household members engaged in agriculture are female. On the other hand, there are more males engaged in non-agricultural jobs than females. In Akwa Ibom, $51.4 \%$ of the household members are engaged in agriculture are female while 48.6 are male. In Rivers State, $78.9 \%$ of the household members are engaged in agriculture are female while $21.1 \%$ are male. In Bayelsa State, $73.1 \%$ of the household members are engaged in agriculture are female while $26.9 \%$ are male. In Delta State, $74 \%$ of the household members are engaged in agriculture are female while $26 \%$ are male. In Ondo State, $77.8 \%$ of the household members are engaged in agriculture are female while $22.2 \%$ are male.
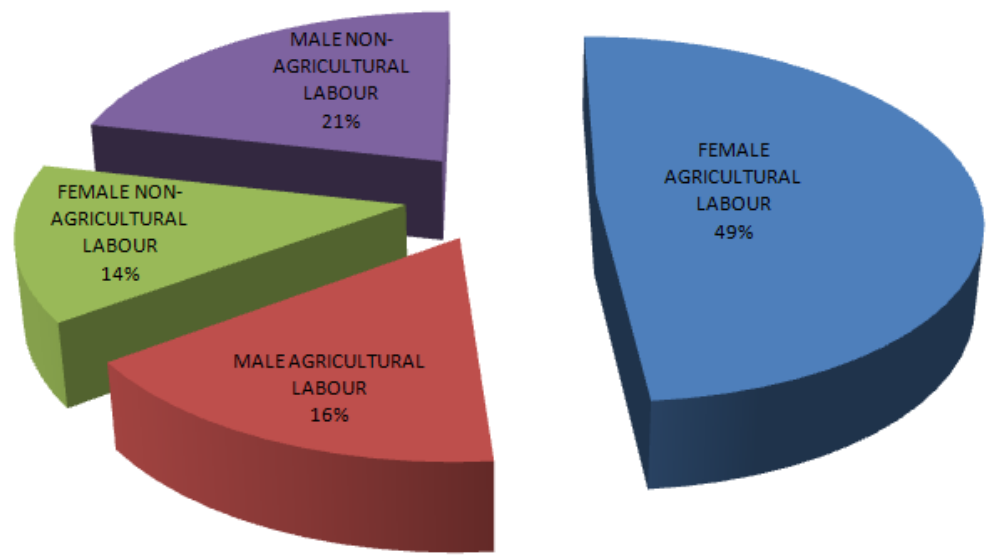

Figure4. Gender distribution of labour in households in the study area 
The gender distribution of labour in households across in the study area is presented in figure 4. Females make up the largest proportion of the labour force. $49 \%$ of the labour force is females engaged in agriculture, $21 \%$ are males engaged in non-agricultural jobs, $16 \%$ are males in agriculture, while $14 \%$ are females in non-agricultural jobs.

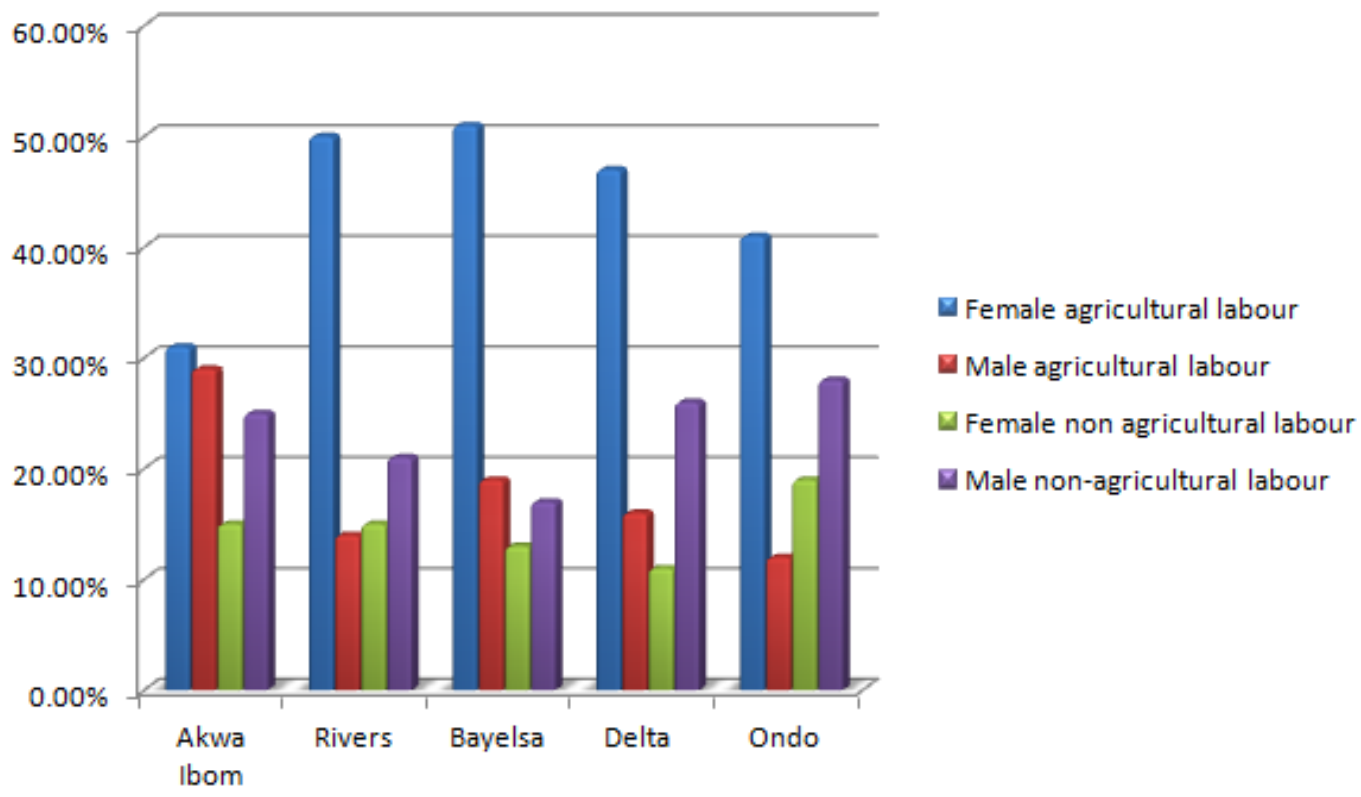

Figure5. Gender distribution of labour in households across States in the study area

The gender distribution of labour in households across States in the study area is shown in Figures 5. It is evident that females agricultural labour constitutes the largest proportionate of the labour force in households. In households across States female agricultural labour constitute $31 \%$ of labour in Akwa Ibom, $50 \%$ of labour in Rivers State, $51 \%$ of labour in Bayelsa State, $47 \%$ of labour in Delta State and $41 \%$ of labour in Ondo State. This is followed by male agricultural labour in Akwa Ibom State (29\%) and Bayelsa State (19\%) and Male non-agricultural labour in Rivers State (21\%), Delta State (26\%) and Ondo State (28\%).

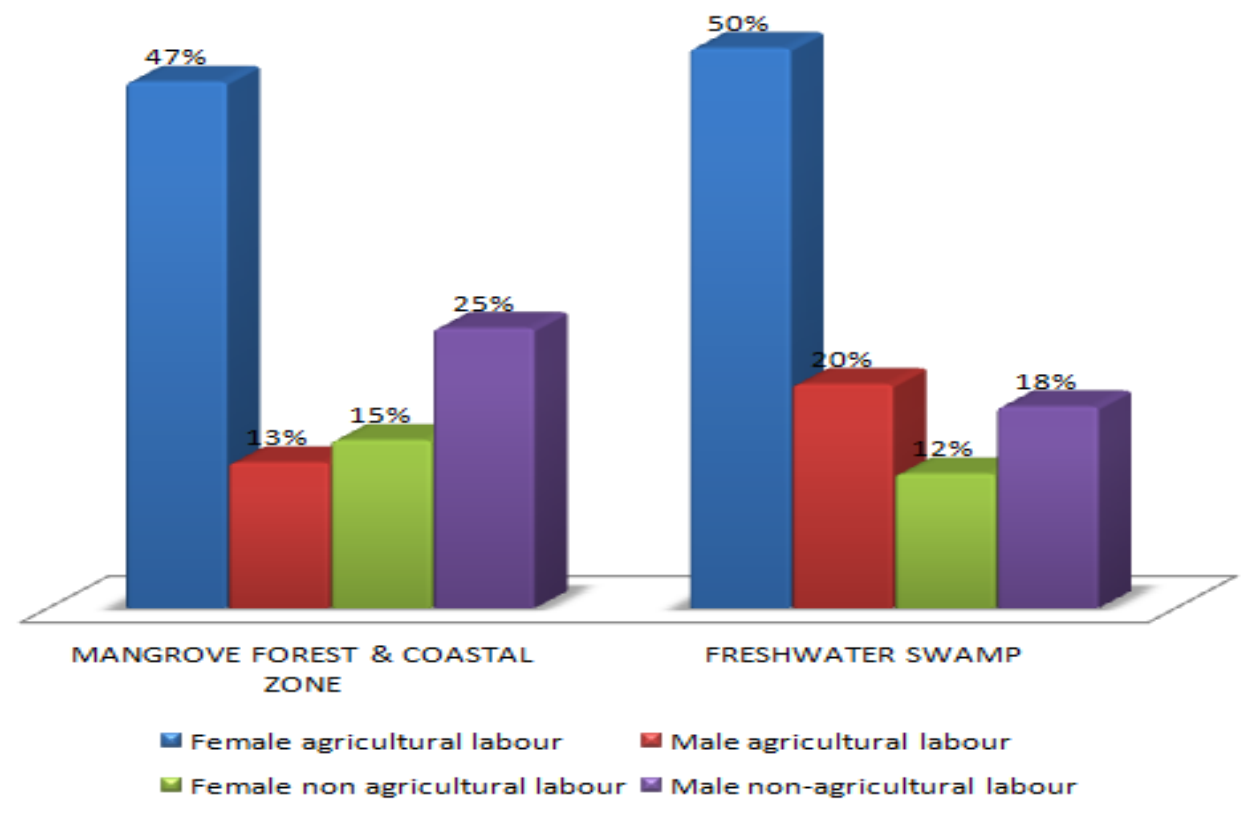

Figure6. Gender distribution of labour in households across States in the study area

The gender distribution of labour in households across ecological zones in the study area is shown in Figures 6. In households across ecological zones female agricultural labour constitutes $47 \%$ of labour in the mangrove forest and coastal zone and 50\% in freshwater swamp zone. This is followed by nonagricultural in the mangrove forest and coastal zone (27\%) and male agricultural labour in freshwater swamp zone (20\%). 


\section{DISCUSSION}

Among households in the study, The results show that females constitute $74.9 \%$ of the agricultural workforce while males constitute $25.1 \%$. Males were more involved in non-agricultural jobs like security, civil service, teaching, boat and motorbike driving, manual labour at building sites, jobs in oil servicing firms and so on. Males constitute $61.1 \%$ of employees in non-agricultural jobs. This agrees with the opinion of Ogunlela and Mukhtar (2009), they assert that there are more women than men engaged in agriculture in Sub-Saharan Africa.

Females constitute over $70 \%$ of the agricultural labour provided by households in the study across the States and ecological zones involved, except in Akwa Ibom where females constitute $54.1 \%$ of the overall agricultural labour provided by households. This disagrees with the findings of SOFA team and Doss (2011) and World Bank (2015) which shows that in SSA, women constitute far less than 60$80 \%$ of agricultural labour. However, they believe that women perform a huge role in agriculture; particularly in developing countries and that these roles vary from one region to another region and even within countries. Also, that summative data can mask these variations. The trend of gender role in agriculture as regards labour supply among households in the study suggests that females may consist of $75 \%$ of agricultural labour in the study area, 51\% in Akwa Ibom, 79\% in Rivers State, $73 \%$ in Bayelsa State, $74 \%$ in Delta State and $78 \%$ in Ondo State. Thus, in rural communities of Ijaw extraction, females may consist of over $70 \%$ of agricultural labour. This agrees with the assertion that women provide $60-80 \%$ of agricultural labour in SSA (Ogunlela \& Mukhtar, 2009) and in Nigeria (Action Aid, 2015).

\section{CONCLUSION AND RECOMMENDATION}

Among households in rural areas, women constitute $74.9 \%$ of the agricultural workforce. The female share of labour in agriculture varies between 73-79\% across States except for Akwa Ibom where it is $51.4 \%$. Thus, there is a need for the National Bureau of Statistics (NBS) to put out gender segregated statistics of the agricultural labour force of various regions in Nigeria, regularly. Consequently the federal Ministry of Agriculture and States Agricultural Development Programmes should especially take care to ensure proper participation of women in policy-making and implementation processes. Males and females involved in agriculture should be proportionally represented in the carrying out of the process either by the male-female ratio of agricultural labour in the regions or by the male-female ratio of the total number of persons in of the area.

\section{REFERENCES}

[1] Abdullahi, Y.Z., Abdullahi, H. and Mohammed, Y. (2012). Food security first: The role of women through empowerment for sustainable food, general security and economic development in Nigeria. European Scientific Journal vol. 8, No.9

[2] Institute of Development Studies (IDS) (2012). Food Security research findings for development policymakers and practitioners. Ed.Turralls. Insights Iss 82, IDS Knowledge Services publication. University of Sussex, Brighton, UK. Retrieved fromwww.eldis.org/insights

[3] FAO (2011).The state of food and Agriculture 2010-11: Women in Agriculture, Closing the gender gap for development. Food and Agriculture Organization of the United Nations, Rome Italy retrieved from http://www.fao.org/docrep/013/i2050e/i2050e.pdf

[4] Saquina, M. (2013).The Role of Rural Women in Agriculture. Retrieved from http://www.wfooma.org/about-wfo.html

[5] Ogunlela, Y.I., \& Mukhtar, A.A. (2009).Gender Issues in Agriculture and Rural Development in Nigeria: The Role of Women. Humanity\& Social Sciences Journal 4 (1): 19-30, 2009 @ IDOSI Publications, 2009.

[6] Rahman, S. A. (2008). Women's involvement in agriculture in northern and southern Kaduna State, Nigeria.Journal of Gender Studies. Vol 17, 17-26

[7] Damisa, M. A., \&Yohanna, M. (2007). Role of rural women in farm management decision making process: Ordered Probit analysis. Trends in Applied Science Research, 2(3): 241-145.

[8] Action Aid (2015). Delivering women farmers' rights. Policy brief. www.actionaid.org, Action Aid, Johannesburg, South Africa.

[9] Afolabi, M.M. (2008). Women as pillars of national economy in Nigeria: A study of economic activities of rural women in six local government areas of Ondo State. IAFFE Summer Conference, International Association for Feminist Economics. Torino, Italy, 19 June- 21 July 2008. 
[10] Fabiyi, E.F., Danladi, B.B., Akande, K.E. \& Mahmood, Y. (2007).Role of Women in Agricultural Development and Their Constraints: A Case Study of Biliri Local Government Area, Gombe State, Nigeria. Pakistan Journal of Nutrition 6 (6): 676-680, 2007 ISSN 1680-5194 (C) Asian Network for Scientific Information, 2007

[11] FAO (1995.) A synthesis report of the African Region: Women, agriculture and rural development. Report prepared under the auspices of FAO's Programme of Assistance in Support of Rural Women in Preparation for the Fourth World Conference o Women; Food and Agriculture Organization of the United Nations, Rome, Italy

[12] World Bank (2015). Agriculture in Africa: Telling facts from Myths. Retrieved from www.worldbank.org/en/programs/

[13] SOFA Team \& Doss, C. (2011). The role of women in Agriculture.ESA Working Paper No. 11-02. Agricultural Development Economics Division, the Food and Agriculture Organization of the United Nations (FAO) for the State Of Food and Agriculture (SOFA) 2010-2011. www.fao.org/economic/esa

Citation: ODUBO Tonye Vivien, et.al, "Participation of Rural Women in Agriculture in Selected States in Niger Delta, Nigeria", International Journal of Research in Environmental Science (IJRES), vol. 5, no. 2, pp. 16-22, 2019. Available: DOI: http://dx.doi.org/10.20431/2454-9444.0502003

Copyright: (C) 2019 Authors. This is an open-access article distributed under the terms of the Creative Commons Attribution License, which permits unrestricted use, distribution, and reproduction in any medium, provided the original author and source are credited. 